\title{
Financing Growth through Foreign Aid and Private Foreign Loans: Nonlinearities and Complementarities
}

\author{
Subhayu Bandyopadhyay, \\ Sajal Lahiri \\ and \\ Javed Younas
}

\author{
Working Paper 2013-031A \\ https://doi.org/10.20955/wp.2013.031
}

October 2013

\author{
FEDERAL RESERVE BANK OF ST. LOUIS \\ Research Division \\ P.O. Box 442 \\ St. Louis, MO 63166
}

The views expressed are those of the individual authors and do not necessarily reflect official positions of the Federal Reserve Bank of St. Louis, the Federal Reserve System, or the Board of Governors.

Federal Reserve Bank of St. Louis Working Papers are preliminary materials circulated to stimulate discussion and critical comment. References in publications to Federal Reserve Bank of St. Louis Working Papers (other than an acknowledgment that the writer has had access to unpublished material) should be cleared with the author or authors. 
This draft: October 10, 2013

\title{
Financing Growth: Foreign Aid vs. Foreign Loans
}

\author{
By \\ Subhayu Bandyopadhyay ${ }^{\S}$, Sajal Lahiri ${ }^{\ddagger}$ and Javed Younas $\$ \$$
}

\begin{abstract}
Compared to foreign grants, do concessional loans from foreign governments and/or unsubsidized loans from foreign private banks lead to faster growth in developing nations? The answer has implications for aid agencies (i) in allocating a given amount of resources between grants and concessional loans; and (ii) in encouraging financial market reforms. We examine the effects of ODA grants, concessional ODA loans, and private offshore bank loans on growth rates of 131 developing nations over 1996-2010 in a unified way. We find evidence of non-linearities in all three relationships, suggesting that at low (high) levels grants are better (worse) than loans (concessional or private).
\end{abstract}

Keywords: Foreign aid, concessional loans, offshore bank loans, economic growth. JEL Classification: F35, O10.

\footnotetext{
$\$$ Federal Reserve Bank of St. Louis, Research Division, PO Box 442, St. Louis, MO 63166-0442, U.S.A.; and Research Fellow at IZA, Bonn, Germany; E-mail: Subhayu.Bandyopadhyay@stls.frb.org

¥Department of Economics, Southern Illinois University Carbondale, Carbondale, IL 62901-4515, U.S.A.; E-mail: lahiri@siu.edu

SS Department of Economics, American University of Sharjah, PO Box 26666, Sharjah, UAE; Email: jyounas@aus.edu

The views expressed are those of the authors and do not necessarily represent official positions of the Federal Reserve Bank of St. Louis or of the Federal Reserve System.
} 


\section{Introduction}

The literature has explored effects of foreign aid on growth. Another strand of the literature has explored effects of credits on growth. In the context of developing nations needing scarce external resources, this poses the following question. Compared to foreign aid, do external loans lead to faster growth in developing nations? This is the central question of our study. The answer has implications for aid agencies (i) in deciding on the allocation of a given amount of aid dollars between grants and concessional loans; and (ii) in encouraging financial market reforms for the inflow of private foreign capital. Our central question also relates to the strand of literature which is critical of foreign aid and suggests that it should be replaced by better access to international credit (see, for example, Bauer, 1971).

Empirical studies on the effectiveness of foreign aid can be broadly classified into three types: foreign aid works (see for example Dalgaard et al., 2004; Hansen and Tarp, 2000); foreign aid does not work (see, for example, Easterly, 2003); and foreign aid works under some conditions (Burnside and Dollar, 2000; Collier and Dollar, 2002). Foreign aid can help foster the economic growth of a developing country through various channels: (i) they add to the investible resources for domestic investment, and, thus, augment capital stock; and (ii) they can bridge the foreign exchange gap of a developing country, which, in turn, may provide it with a necessary cushion to import capital goods. ${ }^{1}$ On the other hand, aid flows can also have effects that are detrimental to the recipient's economy: (i) transfers to the governments may induce politicians to engage in its misappropriation; and (ii) large inflows can result in overvaluation of exchange rate of a recipient country, which may render its exports less competitive in the world market. Since most of foreign aid constitutes direct transfers to governments, its impact on economic growth also depends on how it is utilized. If aid is used to finance complementary goods in developing countries, such as

\footnotetext{
1 These arguments are based on the so-called two-gap model of economic development.
} 
infrastructure and human development, its effect will be positive. But if it crowds out private investment or is used to generate rent seeking activities by politicians, its effect will be negative. As indicated by Harms and Lutz (2006), the net effect of aid on the economy, therefore, will depend on which effect dominates. Recent studies continue to provide mixed guidance. Rajan and Subramanian (2008) do not find any robust relationship between aid inflows and economic growth. Djankov et al. (2008) find that aid may actually worsen the democratic institutions of a nation. Although they do not focus on the effect of aid on growth per se, a worsening of political institutions will likely contribute to greater rent seeking and wastage, and consequently reduced effectiveness of aid. On the other hand, a recent study by Arndt et al. (2010) concludes that aid has significant and positive effects in the long-run. The study warns against the mistake of abolishing foreign aid, and suggests a more nuanced view which focuses on improved aid effectiveness. ${ }^{2}$

On the relationship between international credit and growth, Rajan and Zingales (1998) ask a slightly different but related question: do industries that are relatively more dependent on external finance grow more rapidly in nations with more developed financial markets? Their empirical analysis suggests that this is indeed the case. ${ }^{3}$ This suggests a causal link between external finance and growth, where reductions of cost of external finance may allow a financially dependent firm to grow, or new firms to enter.

As indicated by Arndt et al. (2010), it is important to allow for non-linearities in the aidgrowth relationship. Levine (2005) discusses its importance in the context of the finance-growth

\footnotetext{
2 There is a large literature on different motives for giving aid (see, for example, Alesina and Dollar, 2000).

3 There is a separate, but not directly related to the present context, link between financial development in general and growth. For example, King and Levine (1993) investigate this for a cross-section of nations using a variety of indicators for financial development, including the ratio of assets of "deposit money banks" and the sum of assets of the "deposit money banks" and the respective central banks of different nations in the cross-country analysis. They conclude that "The data are consistent with the view that financial services stimulate economic growth by increasing the rate of capital accumulation and by improving the efficiency with which economies use that capital." Levine (2005) provides a comprehensive survey of this strand of the literature. He concludes that the overall evidence from research on the topic suggests that both financial intermediaries (e.g., banks) and financial markets (e.g., stock markets) are important for growth.
} 
literature. The lack of consensus about the nature of these relationships may have something to do with the absence of a thorough treatment of non-linearities in this literature. The inflow of foreign aid in some countries now constitute $20 \%$ or more of their national income and there have been concerns because of the possible adverse effect of large inflow of foreign aid via their effects on, among others, the exchange rate (see, for example, Mavrotas (2006) for a discussion of the issues). In fact, Hansen and Tarp (2001) do find diminishing returns to aid in promoting growth.

There are theoretical reasons why the relationship between credit and growth can also be non-linear. For example, existence of indivisibilities in investments, such as in Acemoglu and Zilibotti (1997), may give rise to convexities. In early stages of development, risk diversification possibilities are limited, and this leads to investment in less productive but safer projects. As the process of development matures, more of the start-up hurdles are crossed, risk diversification opportunities improve, and consequently more productive investment occurs. This leads to a nonlinear relationship between capital accumulation and growth. Among others, Rioja and Valev (2004) have explored the non-linear relationship between finance and growth. They divide their sample of nations into three groups, low, intermediate and high levels of financial development. They find the strongest positive effects of financial development on growth in the intermediate region, supporting the idea of a convex relationship, at least towards the lower end of the spectrum of financial development.

In this paper, we bring together the two literatures by exploring both the aid-growth and the aid-loans relationships in a single framework. We consider total aid as well as its separate grant and concessional loan components. We also consider loans to the private sector by foreign banks. We also allow for non-linearities in the relationships of these variables with growth. Our panel-data framework draws on 131 aid-recipient countries for the period 1996-2010. Data on foreign aid is collected from the OECD, and to measure a developing nation's access to foreign borrowing in the 
private market, we take offshore bank loans data from the Bank of International Settlements (BIS) Locational Banking Statistics. Our empirical procedure attempts to address a host of estimation issues such as measurement problems, reverse causality, and omitted variables bias - ignoring these would risk estimation bias and inconsistency. We employ alternative econometric techniques and model specifications to ensure that our results are robust. We also examine whether the presence of sample heterogeneity affects our findings, because countries at different levels of income may experience distinct outcomes.

We find interesting patterns of non-linearities. The relationship between grants and growth is an inverted-U one, confirming the diminishing returns findings of Hansen and Tarp (2001), among others. We also find, along the lines of the finance-growth literature, that the loans-growth relationship is U-shaped. The latter is true for concessional loan by aid agencies and credit by foreign banks. Interestingly, we find that the nature of non-linear relationships between the two components of foreign aid, namely grants and concessional loans, are very different, highlighting the importance of separating the two. Taking cue from these non-linearities, we compute critical levels of international transfers such that the marginal effect of grants is larger than that of loans if and only if the transfer (grant, concessional loan or private bank loan) is below the relevant critical level. This suggests that when an aid agency finds itself with a very small amount of resources to allocate, it may choose grants over loans. Otherwise, loans may be the preferred tool.

Section 2 lays out the empirical model and describes the variables and data. Section 3 discusses econometric methodology. Section 4 presents estimation results and robustness analysis. Section 5 concludes. 


\section{Empirical Model and the Description of Variables}

Following the empirical literature on aid and growth, we use the growth rate of real GDP per capita (e.g., Arndt et al., 2010; Burnside and Dollar, 2000; Hansen and Tarp, 2001) to measure the impact of aid on growth. Because we are interested in estimating the relative effectiveness of aid and loans in stimulating growth, we include both of these as explanatory variables. To account for potential non-linearities, we also include squared terms for these central variables. The sample includes 131 developing countries over the period 1996-2010. The reason for choosing this time period is that the cross-border lending data from the Bank of International Settlements for all four quarters is available from 1996. Thus, the relationship takes the following form: ${ }^{4}$

$$
\begin{aligned}
& \text { g\#owth }_{i t}=\beta_{0} \quad \beta_{1}(\text { taid / gdp })_{i t} \quad \beta_{2}(\text { taid / gdp })_{i t}^{2} \quad \beta_{3}(\text { loans / gdp })_{i t} \\
& +\beta_{4}(\text { loans / gdp })_{i t}^{2}+Z_{i t}^{\prime} \theta+\tau_{t}+\eta_{i}+\mu_{i t},
\end{aligned}
$$

where $i$ refers to countries, $t$ to time, $\kappa_{t}$ indicates year-specific effects, $\eta_{i}$ reflects country-specific

effects, and $\mu_{i t}$ is the error term. $Z$ is the vector of commonly used control variables in the literature, which are detailed below. While the time effects account for the impact of time varying common shocks to the economy, the country-specific fixed-effects control for the influence of unobservable factors that may affect the economy. Inclusion of the fixed-effects not only accounts for unobserved heterogeneity, but also reduces biases related to the omission of relevant variables. Our main variables of interest are: aid/gdp, (aid/gdp) ${ }^{2}$, loans/gdp and (loans/gdp) ${ }^{2}$. We further subdivide our aid variable into ODA (Overseas Development Assistance) grants and ODA loans, while our main variable on international loans contains information on private (non-concessional) offshore private bank lending.

\footnotetext{
${ }_{4}^{4}$ Appendix A provides the list of countries in our study. We eliminate Egypt and Israel from our analysis as they receive disproportionately higher amount of aid from the United States for strategic reasons.
} 
Data for foreign assistance, including ODA grants and ODA loans, are taken from the online database of Development Aid Committee (DAC-2012) of the OECD. The aid data consists of net disbursements for development purposes and, hence, does not include military aid. Access to foreign borrowing is gauged by taking offshore bank loans data from the Bank of International Settlements (BIS) Locational Banking Statistics. ${ }^{5}$ These data consist of cross-border loans to all sectors in developing nations from banks situated in the BIS reporting countries. Local lending by banks in a BIS member country is hence not included. For example, loans to India are those from BIS reporting banks located outside of India. Even though India is a BIS reporting country, local lending in foreign currencies by banks situated in India are not included in the cross-border borrowing. The activities of all banking offices residing in each reporting country are measured by the cross-border lending data (based on the residence of the reporting institutions). The aforementioned offices report singularly on their own unconsolidated business, which, thus, includes international transactions with any of their own affiliates. ${ }^{6}$

The quarterly loans data for exchange rate changes are fine-tuned by BIS. BIS also converts the relevant flow of new loans (net of repayments) in each quarter of the year into its original currency using end-of-period exchange rates, and eventually converts the changes in stocks into dollar amounts using period-average exchange rates. Quarterly observations can be converted to annual observations by just adding up data for the four quarters. The data for loans are corrected

\footnotetext{
5 There are a few other data sources for credits in the literature. The Financial Structure Database provides the countrylevel measures of credit constraints which is compiled by Beck et al., (2000) and updated by Beck and Demirgüç-Kunt (2009). Rajan and Zingales (1998) provide the sector level variables such as external finance dependence and asset tangibility, and these have been updated in Chor and Manova (2012). The third is the BIS data (see, for example, Papaioannou (2009) and Hermann and Mihaljek (2011)). The first two sources present us with knowledge on the extent of credit constraints and the third source gives us data on the flow of foreign loans. Since the rationale of this paper is to compare the flow of net foreign aid with that of net foreign loans received by a country, we concentrate on the third source.

${ }^{6}$ Detailed information on the locational banking statistics is available on the BIS website under http://www.bis.org/statistics/.
} 
for the size of the loans recipient country (as in the foreign aid case) as percentage of the GDP of the loans receiving country.

While all of our main econometric specifications include both time-specific and countryspecific fixed effects, we take guidelines from the recent aid-growth literature for the selection of time-variant control variables (e.g., Arndt et al., 2010; Burnside and Dollar, 2000; Hansen and Tarp, 2001). Specifically, we include: investment/GDP as commonly proxied by fixed capital formation, government consumption/GDP, initial real GDP per capita, inflation as measured by GDP deflator, trade openness as measured by export plus imports/GDP and the variable of voice \& accountability to capture formal institutions' effectiveness. ${ }^{7}$ We employ alternative measures of institutional quality to check robustness of our main results. Data for the indicators of institutional quality, i.e., voice and accountability, political stability and absence of violence, rule of law, government effectiveness, regulatory quality, and control of corruption, are taken from Kaufmann et al. (2010; updated 2012). In our sample, the values of these indices range from -2.986 to +1.645 , where a higher score indicates better institutional quality. Data for growth rate of real GDP per capita, initial real GDP per capita, inflation and trade openness are taken from WDI (2012), while data for investment/GDP and government consumption/GDP come from the Penn World Table, compiled by Heston et al., (2011).

We take log transformation of all of main variables of interests because these variables, i.e., foreign aid, ODA grants, ODA loans, offshore bank loans and growth rate of real GDP per capita, exhibit skewed distribution. Their log transformation helps smooth the data and reduces the effect of outliers on estimates. Taking the log of these variables overcomes the measurement problem

\footnotetext{
7 Another valid control variable for inclusion in a growth regression is a factor that may capture the level of human capital stock in a country such as secondary school attainment. Since there are plenty of missing observations in the per annum data for this variable, we do not explicitly include this variable in the regressions as its inclusion results in a substantial reduction in number of observations. However, to check whether our results remain robust with its inclusion, we interpolated missing observations by calculating averages from available values. The findings remain qualitatively and quantitatively similar.
} 
involved with the scaling of different variables. Another important advantage is that, with log transformation, the estimated coefficients can be interpreted as elasticities. The descriptive statistics are reported in Table $1 .^{8}$

[Table 1near here]

\section{The Empirical Methodology}

The issue of establishing causation is a challenge in any growth equation. We take several measures to ensure that our findings are not spurious: First, we report results of our baseline regressions and then sequentially add a myriad of control variables along with time and country-specific fixed effects. Second, we apply alternative econometric techniques on the data - the feasible generalized least squares (FGLS), the first-differenced regressions, and the dynamic difference-generalized method of moments (DGMM) estimator. Finally, we divide our sample countries into different income groups and then conduct our analysis.

Heteroscedasticity and autocorrelation may also bias the estimates. Therefore, we run a series of FGLS regressions where we explicitly allow for the presence of heteroscedasticity across panels and serial correlation within a panel, which gives panel-corrected robust standard errors. Another concern is that it is indeed likely and quite plausible that both foreign aid and foreign loans may be influenced by economic growth in a country, raising concerns about their simultaneous causation in equation (1). A conventional solution to deal with this issue is to use the instrumental variable (IV) approach. This, however, requires the validity of the utilized instruments (and the availability of their data) for potentially endogenous variables such as aid, ODA grants, ODA loans,

\footnotetext{
${ }^{8}$ Data on some observations for some variables, i.e., foreign aid, foreign loans, growth rate of GDP per capita and inflation, exhibit negative values. Following others in the literature, we linearly transform the variables with negative observations by adding a constant of one in their respective minimum values in the sample so that after taking log their lowest value equals zero. This ensures that log transformation does not drop observations with negative values. Note that several past empirical studies on aid have used log-log transformation for deriving estimation result (e.g., Dollar and Levin, 2004; Younas, 2008).
} 
and offshore bank loans. Since we employ the fixed-effects model specification, any chosen instruments should be time-varying. Also, their exclusion restriction in the growth model requires that they should have high correlation with the instrumented variables, but be uncorrelated with the error term, if they are to be valid. Insurmountable difficulty in finding such instruments and their data for multiple endogenous variables, especially when our main variables of interest enter the model in non-linear form, makes this approach infeasible. Indeed, the use of invalid instruments could instead contaminate the estimation results. In view of these limitations, we take one year lagged values of our variables of interest, which reduces their contemporaneous correlation with the dependent variable and alleviates concerns about endogeneity. With these

transformations, equation (1) takes the following form:

$$
\begin{aligned}
& \ln (\text { growth })_{i t}=\beta_{0} \quad \beta_{1} \ln (\text { aid } / \text { gdp })_{i, t-1} \quad \beta_{2}[\ln (\text { aid } / \text { gdp })]_{i, t-1}^{2} \\
& +\beta_{3} \ln (\text { loans } / g d p)_{i, t-1}+\beta_{4}[\ln (\text { loans } / g d p)]_{i, t-1}^{2}+Z_{i t}^{\prime} \theta+\tau_{t}+\eta_{i}+\mu_{i t} \text {. }
\end{aligned}
$$

We acknowledge that the lagging of our variables of interest may not completely resolve the concern about reverse causation in equation (2). Thus, we also check robustness of results by employing the generalized method of moments (GMM) estimation technique, which has also been applied by several recent contributions in the aid-growth literature (e.g., Arndt et al., 2010; Hansen and Tarp, 2001). Although some studies have pointed out that GMM should not be taken as a panacea for all estimation issues, it has been used extensively in the recent literature. ${ }^{9}$ For example, Baltagi et al., (2009) preferred using the difference-GMM (DGMM) for their panel-data analysis of the impact of openness on financial development. They argued that this estimator not only eliminates endogeneity to a great extent, but first differencing of data also ensures that all regressors are stationary (p. 287).

\footnotetext{
${ }^{9}$ See Arndt et al., (2010) for discussion on the application of the GMM estimator in aid-growth literature.
} 
We also employ the dynamic DGMM estimator, as proposed by Arellano and Bond (1991). To tackle the issue of endogeneity, DGMM takes the first difference of the data and then employs lagged values of endogenous variables as their instruments. The literature, however, has pointed out two issues that should to be taken into account when applying this estimator: First, estimates are inconsistent in the presence of autocorrelation in the residuals. For this reason, we employ two specification tests for each regression: (i) second-order serial correlation test to validate the absence of autocorrelation, and (ii) the Sargan test of over-identifying restrictions to confirm the validity of our internal instruments. ${ }^{10}$ If the null hypothesis fails to be rejected, this bolsters support for the model, which is the case in all of our regressions. Second, these tests may lose power when the countries-to-instruments ratio, $r=n / i$, is less than one, where $n$ is the number of countries and $i$ is the number of instruments (e.g., Asiedu and Lien 2011, Roodman, 2009). Note that in almost all of our regressions $r>1$. Furthermore, we use two-step GMM estimation technique in all regressions, which is considered asymptotically efficient and robust to all types of heteroskedasticity (e.g., Asiedu and Lien, 2011). First differencing of the DGMM model eliminates the time invariant countryspecific fixed-effects, and thus the relationship that we estimate will take the following form:

$$
\begin{aligned}
& \ln (\text { growth })_{i t}-\ln (\text { grow } * h)_{i, t-1}=\beta_{0} \quad \beta_{1}\left[\ln (\text { aid } / \text { gdp })_{i, t-1} \ln (\text { aid } / \text { gdp })_{i, t-2}\right] \\
& +\beta_{2}\left[\begin{array}{ll}
\{\ln (\text { aid } / \text { gdp })\}_{i, t-1}^{2}-\{\ln (\text { aid } / \text { gdp })\}_{i, t-2}^{2}
\end{array}\right] \\
& +\beta_{3}\left[\ln (\text { loans } / \text { gdp })_{i, t-1}-\ln (\text { loans } / \text { gdp })_{i, t-2}\right] \\
& +\beta_{4}\left[\{\ln (\text { loans } / \text { gdp })\}_{i, t-1}^{2}-\{\ln (\text { loans } / \text { gdp })\}_{i, t-2}^{2}\right] \\
& +\gamma\left[\ln (\text { growth })_{i, t-1}-\ln (\text { growth })_{i, t-2}\right]+\left(Z_{i t}^{\prime} \theta-Z_{i, t-1}^{\prime} \theta\right)+\left(\tau_{t}-\tau_{t-1}\right)+\left(\mu_{i t}-\mu_{i, t-1}\right) .
\end{aligned}
$$

\footnotetext{
${ }^{10}$ We treat all explanatory variables as endogenous and only utilize their internal instruments generated in the model.
} 


\section{Estimation Results}

\subsection{Baseline regressions}

In Table 2, we report results of our baseline regressions by applying FGLS estimation technique, where we only include our primary variables of interest. In columns (1-4), we first estimate the model by imposing the restriction that both time and country-specific fixed-effects, which account for other influences of growth and omitted factors bias, do not matter (i.e., $\tau_{t}=0 \forall t$, and $\eta_{i}=0 \forall i$ ). Column (1) regresses log growth rate of real GDP per capita on log aid/GDP, log offshore bank loans/GDP and their squared terms. Columns (2) and (3) subdivide aid into ODA grants and ODA loans, respectively. Column (4) includes all of our main variables of interest, i.e., log ODA grants/GDP, log ODA loans/GDP, log offshore loans/GDP and their squared terms. Columns (58) repeat this exercise by also including both time and country-specific fixed-effects in each specification. In Table 3, we take first-difference of the data and report estimation results. Note that first differencing eliminates the country-specific fixed effects. The results show that the coefficients of log offshore bank loans/GDP and its squared term are statistically significant in all the regressions and their signs are as expected. However, the coefficients of log aid/GDP and its subdivided components (i.e., log ODA grants/GDP, log ODA loans/GDP and their squared terms) are mainly statistically significant in the regressions that include both time and country-specific fixed-effects (columns 5-8 in Table 2 and columns 1-4 in Table 3). Their signs also agree with the concavity of the aid-growth and the convexity of the finance-growth relationship one may expect based on the existing literature. In contrast to the diminishing marginal effect of aid and of ODA grants on growth, both ODA loans and offshore bank loans have an increasing marginal effect on growth. These baseline regression results suggest that models that account for unobserved country level heterogeneity and common time shocks to the economy perform better. In the following section, we check for robustness of our results by sequentially including a number of control 
variables and applying alternative econometric techniques to the data.

[Tables $2 \& 3$ near here]

\subsection{Fully specified model}

In Table 4, we report results for our fully specified models by including a full set of control variables as mentioned above. All of these regressions include both time and country-specific fixed-effects. Columns (1) through (4) present results of FGLS regressions. In column (1), the positively significant coefficient of log aid/GDP and negatively significant coefficient of its squared term confirm its diminishing marginal impact on growth. This finding implies that while some countries may utilize aid effectively, others lack the absorptive capacity or institutional quality with which to complement aid. ${ }^{11}$ As also pointed out by Harms and Lutz (2006), this also indicates that, after reaching a threshold level, the negative rent seeking effect of aid dominates its positive infrastructure building effect. On the other hand, the negatively significant coefficient of log offshore bank loans/GDP and positively significant coefficient of its squared term point to its increasing marginal return on growth, as may be anticipated in the light of Acemoglu and Zilibotti (1997).

Next, we split the aid variable into ODA grants and ODA loans to determine whether the diminishing marginal effect of aid is being reflected from its grants or its loans component, or from both. Accordingly, our revised estimating equation takes the form:

$$
\begin{aligned}
& \ln (\text { growth })_{i t}=\beta_{0} \quad \beta_{1} \ln \left(\text { ODAgrants / gdp } \oiint_{i, t-1} \quad \beta_{2}[\ln (\text { ODAgrants / gdp })]_{i, t-1}^{2}\right. \\
& +\beta_{3} \ln (\text { ODAloans / gdp })_{i, t-1}+\beta_{4}[\ln (\text { ODAloans } / \text { gdp })]_{i, t-1}^{2} \\
& +\beta_{5} \ln (\text { OffshoreBankLoans } / \text { gdp })_{i, t-1}+\beta_{6}[\ln (\text { OffshoreBankLoans } / \text { gdp })]_{i, t-1}^{2} \\
& +Z_{i t}^{\prime} \theta+\tau_{t}+\eta_{i}+\mu_{i t} .
\end{aligned}
$$

\footnotetext{
11 See Hansen and Tarp (2001) for a detailed discussion on the theoretical argument about non-linear effect of aid on economic growth, which relate to absorptive capacity constraints, Dutch disease and institutional destruction problems in developing countries.
} 
First, we include these two components of aid separately (columns 2-3), then we include them together in the regressions (column 4). Their signs and statistical significance show the inverted-U shaped relationship between ODA grants and growth, but a U-shaped relationship between ODA loans and growth. Past studies attribute the finding of diminishing marginal impact of aid to absorptive capacity constraints, Dutch disease and institutional weaknesses in developing countries. Our findings reveal that this relationship stems from the grant component of aid only, while the loans component, in fact, has an increasing marginal impact on growth. The regressions results of the first-differenced regression are also qualitatively and quantitatively the similar (columns 5-8).

[Table 4 near here]

In a footnote to Table 4, we evaluate and report the marginal effect of aid, ODA grants, ODA loans and offshore bank loans on growth at their mean values, which stand at 2.075, 1.43, 4.858, and 5.95, respectively. In column (1), the marginal effect of aid is 0.047 [0.084 $-2 \times(0.009) \times$ (2.08)], while the marginal effect of ODA grants is 0.05 [0.096 $-2 \times(0.016) \times(1.43)]$. Interestingly, this marginal impact of aid (grants) declines when it is evaluated at higher than mean value in our sample. For example, this effect of aid (grants) is $0.036(0.024)$ and $0.029(0.005)$ when we evaluate at its $75^{\text {th }}$ and $90^{\text {th }}$ percentile levels in our sample, respectively. This suggests that although aid (grants) is more effective at its low level, its marginal effect decreases at increasing rate at the higher level of such transfer. In part, this finding appears to appeal to the morals of giving aid as underscored by Stern (1974), who argues for the transfer from the rich to the poor if the benefit to the latter justifies the cost to the former.

In column (3), we evaluate and report the marginal effect of ODA loans and offshore bank loans on growth at their mean values, which stand at 4.86 and 5.95 in our sample, respectively. The marginal effect of the former is $0.078[-0.107+2 \times(0.019) \times(4.86)]$, while the marginal effect of the 
latter is $0.631[-0.916+2 \times(0.130) \times(5.95)]$. Notice that: (i) the marginal effect of offshore bank loans on growth is 8.09 times larger than the marginal effect of ODA loans; and (ii) the marginal effect of both these types of transfers is larger than the marginal effect of aid or grants on growth. That effect, in fact, is substantially larger in the case of offshore bank loans. Calculations in column (4), where we include ODA grants, ODA loans and offshore bank loans together in the regression, reveal similar results. These findings suggests that starting at the mean level, an increase in aid (grants) leads to a reduction in its positive marginal effect on growth, while an increase in both types of loans causes an increase in their positive marginal effects on growth. This also implies that at lower level of transfers, grants have larger positive effects on growth compared to loans.

The marginal effects of each type of transfers computed above have been calculated at their mean values. However, it is of interest to compute the critical level of each of ODA grants vs. ODA loans, and ODA grants vs. offshore bank loans, below (above) which the marginal effect of ODA grants (loans) may be larger. First, we compute the value of $\mathrm{X}$ by equating the marginal effect of ODA grants with the marginal effect of ODA loans, i.e., $\beta_{1}+2 \times \beta_{2} \times X=\beta_{3}+2 \times \beta_{4} \times X$. Similarly, we compute the value of $\mathrm{Y}$ by equating the marginal effect of ODA grants with the marginal effect of offshore bank loans, i.e., $\beta_{1}+2 \times \beta_{2} \times Y=\beta_{5}+2 \times \beta_{6} \times Y$. For these calculations, we use the coefficients in the fully specified model in column 4 of table 2 . These values of X and Y are 3.048 and 3.48, respectively, which are higher than the mean value of $\log$ ODA grant/GDP and lower than the mean values of both log ODA loans/GDP and of log offshore bank loans/GDP. Our results that we derive using the first-differenced regressions and calculations of the marginal effects and of the critical values are qualitatively the same (columns 5-8).

Figures 1, 2 and 3 plot the estimated effect of log ODA grants/GDP, log ODA loans/GDP and log offshore loans/GDP on fitted values of log growth rate of real income per capita, respectively. Over most of the range of log ODA grants/GDP, lower levels of grants are associated 
with higher level of economic growth. This effect, however, diminishes with higher levels of grants, suggesting its inverted U-shaped relationship with growth. On other hand, lower levels of both ODA loans and offshore bank loans cause downward pressure on economic growth, while after reaching a certain threshold level their positive effect dominates their negative effect suggesting their inverted U-shaped relationship with growth.

[Figures 1, 2 and 3 near here]

We now briefly discuss the results of control variables. Our results strongly support the past findings that domestic investment, trade openness and institutional quality (as proxied by voice and accountability) positively affect growth, while government consumption and inflation have negative influence on growth. The sign of $\log$ initial GDP per capita is negative in all the FGLS regressions, while its sign is positive in all the first-differenced regressions; however, none of its coefficient are found to be statistically significant.

Many past studies state that employing different control variables can change the results in growth regression (see, for example, Dollar and Levin, 2004). Thus, we check whether the results of our variables of interest are robust to the introduction of alternative institutional quality indicators that may explain growth. In Table 5, we replace voice and accountability with political stability, government effectiveness, regulatory quality, rule of law and control of corruption, one at a time. These results show that the sign, significance and even the magnitude of the coefficients of the main variables remain the same with the inclusion of different institutional variables. All these results support the past assertion that institutions are important for growth. Similar exercise for the firstdifferenced regressions provides the same results. To conserve space, those results are not reported here.

[Table 5 near here] 


\subsection{Analysis at different income levels}

In this section, we check whether our results are qualitatively the same when we apply our analysis to countries which are at the different levels of income. Thus, we divide our sample into four category: (i) countries with real GDP per capita less than $25^{\text {th }}$ percentile (403.68 USD); (ii) countries with real GDP per capita less than $50^{\text {th }}$ percentile (1116 USD); (iii) countries with real GDP per capita less than mean level (2229.53 USD); and (iv) countries with real GDP per capita less than $75^{\text {th }}$ percentile level (3029.77 USD). There are a total of 38, 71, 94 and 101 countries in the first, second, third and fourth group, respectively. In Table 6, columns (1-4) reports results for the FGLS, while columns (5-8) presents results for the DGMM regressions. These results strongly reinforce our above findings, except that the coefficients of log ODA grants/GDP and its squared terms are not statistically significant in columns 5 and 6 . We also calculate and report the marginal effects and critical values of ODA grants, ODA loans and offshore bank loans in Table 6. These values draw the similar conclusion as in Tables 4 and 5. Note that the coefficient of log initial GDP per capita, which was statistically insignificant in Tables 4 and 5, is negative and significant in 7 out of 8 regressions in Table 6. In all the DGMM regressions, p-values of Sargan and autocorrelation tests confirm the validity of instruments and the absence of second-order serial correlation in the residuals, respectively.

[Table 6 near here]

We also check the robustness of our results by excluding Oil Producing and Exporting Countries (OPEC) and Transition economies from our regressions. OPEC economies generate high foreign reserves from sale of oil and petroleum products in the international market. Therefore, their dependence on foreign aid for financing development projects is minimal. In fact, allocation of foreign aid to these economies has been quite low in our sample period, and most of the aid flows to them has been mainly comprised of humanitarian assistance and of ODA loans. On 
the other hand, starting in the early 1990s, Transition economies received substantially larger amounts of aid to support their transition to the free market system and new political regimes. Our main findings remain intact with the exclusion of these economies. ${ }^{12}$

\section{Concluding Remarks}

Should foreign aid be replaced by concessional loans or an easier access to international credit markets? One way to approach this question is to see which policy is more effective in spurring growth in developing nations. Accordingly, we pursue an empirical strategy of uncovering the relationship between growth, aid and loans for a cross-section of developing nations. We find that the growth-grant relationship is an inverted- $U$ one, suggesting strong diminishing returns. This tends to reduce the desirability of grants at high levels. On the other hand, we find that the relationship between loans and growth is U-shaped, suggesting increasing returns, and hence an argument to expand loans from initial levels that are beyond a critical level.

We should note that offshore bank loans are a market determined variable, and so whether they should be substituted by (or substituted for) aid is not a directly relevant policy question.

However, reforms in the financial market can induce more inflow of private foreign capital and thus policies can indirectly affect private international credits. Moreover, aid itself has a loan and a grant component. Our study shows that the loan component of aid exhibits increasing returns, while the grant component has the traditional concave relationship with growth. Thus, it is very important to separate out the two components of foreign aid in examining the aid-growth relationship.

Accordingly, we can suggest two things: (i) if loans are used by aid agencies, they should be used in large quantities to avail of increasing returns; (ii) facing binding resource constraints, the aid agencies have to determine precisely where a particular developing nation is on their grant-growth or loans-

\footnotetext{
12 To save space, these results are not reported in the paper; however, they are available from the authors upon request.
} 
growth curves to have a definitive answer on whether aid or loans may be a better tool at the margin. Finally, our findings suggest that where financial markets are not well-developed, availing of increasing returns will require major policy reforms to ease international capital flows, such that tangible growth benefits may be realized. 


\section{References}

Acemoglu, D. and Zilibotti, F. (1997). "Was Prometheus Unbound by Chance? Risk, Diversification, and Growth," Journal of Political Economy, 105(4), 709-751.

Alesina, A. and Dollar, D. (2000). "Who gives foreign aid to whom and why?", Journal of Economic Growth, 5, 33-63.

Arellano, M. and Bond, S. R. (1991). "Some tests of specification for panel data: monte carlo evidence and an application to employment equations," Review of Economic Studies, 58, 277-97.

Arndt, C., Jones, S. and Tarp, F. (2010). "Aid, growth, and development: have we come full circle?", Journal of Globalization and Development, 1(2), Article 5.

Asiedu, E. and Lien, D. (2011). "Democracy, foreign direct investment, and natural resources." Journal of International Economics, 84, 99-111.

Baltagi, B.H., Demetriades, P.O., and Law, S.H. (2009) Financial development and openness: evidence from panel data, Journal of Development Economics, 89, 285-96.

Bauer, P.T. (1971). Dissent on Development, London: Widenfeld and Nicolson.

Beck, T., Demirgüç-Kunt, A. and Levine, R. (2000). "A new database on financial development and structure," World Bank Economic Review, 14, 597-605.

Beck, T. and Demirgüç-Kunt, A. (2009). "Financial institutions and markets across countries and over time: data and analysis", World Bank Policy Research Working Paper No. 4943.

Burnside, C. and Dollar, D. (2000). "Aid, policies, and growth," American Economic Review, 90, 847868.

Chor, D. and Manova, K. (2012). "Off the cliff and back? Credit conditions and international trade during the global financial crisis," Journal of International Economics, 87, 117-133.

Collier, P. and Dollar, D. (2002). "Aid allocation and poverty reduction," European Economic Review, $45,1-26$.

Dollar, D. and Levin, V. (2004). “The increasing selectivity of foreign aid, 1984-2002," World Bank Policy Research Paper 3299.

Dalgaard, C.J., Hansen, H. and Tarp, F. (2004). "On the empirics of aid and growth," Economic Journal, 114, 191-216.

Djankov, S., Montalvo, J.G., and Reynal-Querol M. (2008). “The curse of aid,” Journal of Economic Growth, 13, 169-194. 
Dudley, L. and Montmarquette, C. (1976). "A model of supply of bilateral aid foreign aid," American Economic Review, 66, 132-142.

Easterly, W. (2003). "Can foreign aid buy growth?" Journal of Economic Perspectives, 17, 23-48.

Freedom House (2010). Freedom in the World, Freedom House, New York.

Hansen, H. and Tarp, F. (2000). "Aid effectiveness disputed," Journal of International Development, 12, 375-398.

Hansen H. and Tarp, F. (2001). "Aid and growth regressions," Journal of Development Economics, 64, 547-570.

Harms, P. and Lutz, M. (2006). "Aid, governance and private foreign investment: some puzzling findings for the 1990s," Economic Journal, 116, 773-790.

Heston, A., Summers, R., Aten, B., (2011). Penn World Table Version 7.0, Center for International Comparisons of Production, Income and Prices at the University of Pennsylvania.

Hermann, S. and Mihaljek, D. (2011). "The determinants of cross-border bank flows to emerging markets: new evidence on the spread of financial crises," Bank of Finland Working Paper No. 3-2011.

Kaufmann, D., Kraay, A. and Mastruzzi, M. (2010). "The worldwide governance indicators: A summary of methodology, data and analytical issue," World Bank Policy Research Working paper No. 5430. Updated 2012. http://info.worldbank.org/governance/wgi/sc country.asp

King, R.G. and Levine, R. (1993). "Finance and Growth: Schumpeter Might Be Right". Quarterly Journal of Economics, 108(3), 717-736.

Levine, R. (2005). "Finance and Growth: Theory and Evidence". Handbook of Economic Growth, Volume 1A, 865-934. Eds. Philippe Aghion and Steven N. Durlauf. Elsevier B.V.

Mavrotas, G. (2006). "Scaling up of foreign aid and the emerging new agenda," Chapter 13 in Lahiri, S. (ed.), Theory and Practice of Foreign aid (Frontiers of Economics and Globalization, Volume 1), Emerald Group Publishing Limited, pp. 211-233.

Papaioannou, E. (2009). "What drives international financial flows? politics, institutions and other determinants," Journal of Development Economics, 88, 269-281.

Rajan, R. and Subramanian, A. (2008) "Aid and Growth: What Does the Cross-Country Evidence Really Show?," The Review of Economics and Statistics, 90(4), 643-665.

Rajan, R. and Zingales, L. (1998) "Financial dependence and growth," American Economic Review, 88, 559-586.

Rioja, F. and Valev, N. (2004) "Does one size fit all?: A reexamination of the finance and growth relationship," Journal of Development Economics, 74, 429-447. 
Roodman, D. (2009). "A note on the theme of too many instruments," Oxford Bulletin of Economics and Statistics, 71, 135-58.

Stern, N.H. (1974). "Professor Bauer on development: a review article," Journal of Development Economics, 1, 191-211.

World Bank (2012). World Development Indicators, 2012. World Bank, Washington, DC.

Younas, J. (2008). "Motivation for bilateral aid allocation: altruism or trade benefits," European Journal of Political Economy, 24, 661-674. 
Table 1: Summary statistics

\begin{tabular}{lrrrrr}
\hline \hline Variables & Obs. & \multicolumn{1}{c}{ Mean } & \multicolumn{1}{c}{ S.D. } & Min & \multicolumn{1}{c}{ Max } \\
\hline Ln (Growth rate of real GDP per capita) & 1938 & 3.614 & 0.164 & 0.000 & 4.847 \\
Ln (ODA aid/GDP) & 1906 & 2.075 & 0.709 & 0.000 & 5.014 \\
Ln (ODA grants/GDP) & 1906 & 1.430 & 1.053 & 0.000 & 5.100 \\
Ln (ODA loans/GDP) & 1906 & 4.858 & 0.118 & 0.000 & 5.145 \\
Ln (Offshore bank loans/GDP) & 1955 & 5.950 & 0.140 & 0.000 & 6.612 \\
Investment/GDP & 1965 & 23.220 & 11.390 & 1.722 & 88.004 \\
Government consumption/GDP & 1965 & 12.271 & 7.930 & 0.928 & 58.001 \\
Ln (Initial GDP per capita) & 1931 & 6.885 & 1.190 & 4.079 & 9.367 \\
Ln (Inflation) & 1936 & 3.756 & 0.365 & 0.000 & 8.600 \\
Trade/GDP & 1965 & 83.893 & 40.169 & 14.074 & 265.687 \\
Voice \& accountability & 1965 & -0.377 & 0.821 & -2.158 & 1.471 \\
Political stability & 1944 & -0.344 & 0.888 & -2.986 & 1.544 \\
Government effectiveness & 1946 & -0.423 & 0.646 & -2.248 & 1.590 \\
Regulatory quality & 1947 & -0.407 & 0.702 & -2.675 & 1.645 \\
Rule of law & 1965 & -0.456 & 0.714 & -2.234 & 1.599 \\
Corruption & 1946 & -0.429 & 0.635 & -2.057 & 1.553 \\
\hline
\end{tabular}

Notes: The data span over the period 1996-2010. ODA stands for official development assistance. In this study, we use data of net disbursement of ODA. All of the ratios are denoted as percentage of GDP. Offshore bank loan data from Bank for International Settlement (BIS) is adjusted for exchange rate movements (done by BIS). 
Table 2: Baseline regressions

Dependent variable: Ln (Growth rate of real GDP per capita)

\begin{tabular}{|c|c|c|c|c|c|c|c|c|}
\hline \multirow[b]{2}{*}{ Independent variables $\downarrow$} & \multicolumn{3}{|c|}{ Without fixed effects } & \multirow[b]{2}{*}{ (4) } & \multicolumn{3}{|c|}{ With fixed effects } & \multirow[b]{2}{*}{$(8)$} \\
\hline & $(1)$ & (2) & (3) & & $(5)$ & (6) & $(7)$ & \\
\hline $\operatorname{Ln}(O D A \text { aid } / G D P)_{, t-1}$ & $\begin{array}{l}-0.007 \\
(0.778)\end{array}$ & & & & $\begin{array}{l}0.094^{* * *} \\
(0.008)\end{array}$ & & & \\
\hline$[\operatorname{Ln}(O D A \text { aid } / G D P)]^{2}, t-1$ & $\begin{array}{c}0.001 \\
(0.938)\end{array}$ & & & & $\begin{array}{l}-0.011 \\
(0.118)\end{array}$ & & & \\
\hline Ln $(O D A \text { grants } / G D P)_{, t-1}$ & & $\begin{array}{l}-0.012^{*} \\
(0.063)\end{array}$ & & $\begin{array}{l}-0.007 \\
(0.390)\end{array}$ & & $\begin{array}{l}0.105^{* * *} \\
(0.000)\end{array}$ & & $\begin{array}{l}0.108^{* * *} \\
(0.000)\end{array}$ \\
\hline$[\mathrm{Ln}(\mathrm{OD} \text { A grants } / G D P)]^{2}, t-1$ & & $\begin{array}{c}0.002 \\
(0.200)\end{array}$ & & $\begin{array}{c}0.001 \\
(0.821)\end{array}$ & & $\begin{array}{l}-0.017^{* * *} \\
(0.000)\end{array}$ & & $\begin{array}{l}-0.017^{* * *} \\
(0.000)\end{array}$ \\
\hline Ln $(O D A \text { loans } / G D P)_{, t-1}$ & & & $\begin{array}{l}-0.018 \\
(0.699)\end{array}$ & $\begin{array}{l}-0.016 \\
(0.798)\end{array}$ & & & $\begin{array}{l}-0.064 \\
(0.241)\end{array}$ & $\begin{array}{l}-0.122^{*} \\
(0.076)\end{array}$ \\
\hline$[\operatorname{Ln}(O D A \text { loans } / G D P)]^{2}, t-1$ & & & $\begin{array}{l}-0.004 \\
(0.958)\end{array}$ & $\begin{array}{l}-0.002 \\
(0.850)\end{array}$ & & & $\begin{array}{c}0.011 \\
(0.258)\end{array}$ & $\begin{array}{c}0.021 \\
(0.139)\end{array}$ \\
\hline Ln (Offshore bank. loans/GDP),t-1 & $\begin{array}{l}-0.781^{* *} \\
(0.019)\end{array}$ & $\begin{array}{l}-0.760^{* *} \\
(0.023)\end{array}$ & $\begin{array}{l}-0.738^{* *} \\
(0.027)\end{array}$ & $\begin{array}{l}-0.767^{* *} \\
(0.022)\end{array}$ & $\begin{array}{l}-1.177^{* * *} \\
(0.000)\end{array}$ & $\begin{array}{l}-1.225^{* * *} \\
(0.003)\end{array}$ & $\begin{array}{l}-1.128^{* * *} \\
(0.000)\end{array}$ & $\begin{array}{l}-1.191^{\text {**** }} \\
(0.000)\end{array}$ \\
\hline$[\mathrm{Ln} \text { (Offshore bank loans/GDP) }]^{2}, t-1$ & $\begin{array}{l}0.111^{* * *} \\
(0.001)\end{array}$ & $\begin{array}{l}0.107^{* * *} \\
(0.001)\end{array}$ & $\begin{array}{l}0.103^{* * *} \\
(0.002)\end{array}$ & $\begin{array}{l}0.108^{* * *} \\
(0.001)\end{array}$ & $\begin{array}{l}0.172^{* * *} \\
(0.000)\end{array}$ & $\begin{array}{l}0.181^{* * *} \\
(0.000)\end{array}$ & $\begin{array}{l}0.165^{* * *} \\
(0.000)\end{array}$ & $\begin{array}{l}0.176^{* * *} \\
(0.000)\end{array}$ \\
\hline Time effects & No & No & No & No & Yes & Yes & Yes & Yes \\
\hline Country fixed effects & No & No & No & No & Yes & Yes & Yes & Yes \\
\hline \# of observations & 1762 & 1762 & 1762 & 1762 & 1762 & 1762 & 1762 & 1762 \\
\hline \# of countries & 131 & 131 & 131 & 131 & 131 & 131 & 131 & 131 \\
\hline Wald chi-square & 23.7 & 26.1 & 19.5 & 28.6 & 2079.5 & 1972.5 & 1906.0 & 2025.8 \\
\hline $\begin{array}{l}\text { Joint significance: aid \& aid sq. } \\
\text { Joint significance: grants \& grants sq. } \\
\text { Joint significance: loans \& loan sq. }\end{array}$ & & 0.072 & & & 0.000 & & & 0.106 \\
\hline
\end{tabular}


Table 3: Baseline regressions

Dependent variable: $\Delta \mathrm{Ln}$ (Growth rate of real GDP per capita)

\begin{tabular}{|c|c|c|c|c|}
\hline \multirow[b]{2}{*}{ Independent variables $\downarrow$} & \multicolumn{3}{|c|}{ 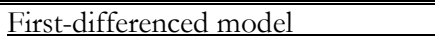 } & \multirow[b]{2}{*}{ (4) } \\
\hline & $(1)$ & $(2)$ & (3) & \\
\hline$\Delta L n(O D A \text { aid } / G D P)_{, t-1}$ & $\begin{array}{l}0.104^{* * *} \\
(0.010)\end{array}$ & & & \\
\hline$\Delta[\operatorname{Ln}(O D A$ aid $/ G D P)]]^{2}, t-1$ & $\begin{array}{l}-0.016^{* *} \\
(0.043)\end{array}$ & & & \\
\hline$\Delta L n(O D A \text { grants } / G D P)_{, t-1}$ & & $\begin{array}{l}0.094^{* * *} \\
(0.000)\end{array}$ & & $\begin{array}{c}0.099^{* * * *} \\
(0.000)\end{array}$ \\
\hline$\Delta[\operatorname{Ln}(O D A \text { grants } / G D P)]^{2}, t-1$ & & $\begin{array}{l}-0.018^{* * *} \\
(0.000)\end{array}$ & & $\begin{array}{l}-0.019^{* * *} \\
(0.000)\end{array}$ \\
\hline$\Delta L n(O D A \text { loans } / G D P)_{, t-1}$ & & & $\begin{array}{l}-0.145^{* *} \\
(0.021)\end{array}$ & $\begin{array}{l}-0.127 \\
(0.106)\end{array}$ \\
\hline$\Delta[\operatorname{Ln}(O D A \text { loans } / G D P)]^{2}, t-1$ & & & $\begin{array}{l}0.048^{* * *} \\
(0.010)\end{array}$ & $\begin{array}{c}0.019 \\
(0.218)\end{array}$ \\
\hline$\Delta L n$ (Offshore bank loans/GDP),t-1 & $\begin{array}{l}-0.925^{* * *} \\
(0.003)\end{array}$ & $\begin{array}{l}-0.965^{* * *} \\
(0.002)\end{array}$ & $\begin{array}{l}-0.925^{* * *} \\
(0.003)\end{array}$ & $\begin{array}{l}-0.934^{* * *} \\
(0.003)\end{array}$ \\
\hline$\Delta[\text { Ln (Offshore bank loans/GDP) }]^{2}, t-1$ & $\begin{array}{l}0.102^{* * *} \\
(0.001)\end{array}$ & $\begin{array}{l}0.109^{* * *} \\
(0.001)\end{array}$ & $\begin{array}{l}0.102^{* * *} \\
(0.002)\end{array}$ & $\begin{array}{l}0.104^{* * *} \\
(0.001)\end{array}$ \\
\hline Time effects & Yes & Yes & Yes & Yes \\
\hline \# of observations & 1630 & 1630 & 1630 & 1630 \\
\hline \# of countries & 131 & 131 & 131 & 131 \\
\hline Wald chi-square & 355.3 & 379.9 & 358.3 & 372.6 \\
\hline
\end{tabular}

Notes: The first-differencing of the data eliminate the country-specific fixed effects. Other notes are same as of Table 2. 
Table 4

Dependent variable: $\mathrm{Ln}$ (Growth rate of real GDP per capita)

\begin{tabular}{|c|c|c|c|c|c|c|c|c|}
\hline \multirow{2}{*}{$\begin{array}{l}\text { Estimation technique } \rightarrow \\
\text { Independent variables } \downarrow\end{array}$} & \multicolumn{4}{|c|}{ With fixed effects } & \multicolumn{4}{|c|}{ First-differenced } \\
\hline & $(1)$ & (2) & (3) & (4) & (5) & (6) & (7) & (8) \\
\hline $\operatorname{Ln}(O D A \text { aid } / G D P)_{, t-1}$ & $\begin{array}{l}0.084^{* *} \\
(0.020)\end{array}$ & & & & $\begin{array}{l}0.120^{* * *} \\
(0.003)\end{array}$ & & & \\
\hline$[\mathrm{Ln}(\mathrm{OD} A \text { aid } / G D P)]^{2}, t-1$ & $\begin{array}{l}-0.009 \\
(0.191)\end{array}$ & & & & $\begin{array}{l}-0.019^{* *} \\
(0.020)\end{array}$ & & & \\
\hline Ln $(O D A \text { grants } / G D P)_{, t-1}$ & & $\begin{array}{l}0.096^{* * *} \\
(0.000)\end{array}$ & & $\begin{array}{l}0.098^{* * *} \\
(0.000)\end{array}$ & & $\begin{array}{l}0.090^{* * *} \\
(0.000)\end{array}$ & & $\begin{array}{l}0.095^{* * *} \\
(0.000)\end{array}$ \\
\hline$[\mathrm{Ln}(\mathrm{OD} \text { A grants } / G D P)]^{2}, t-1$ & & $\begin{array}{l}-0.016^{* * * *} \\
(0.000)\end{array}$ & & $\begin{array}{l}-0.015^{* * *} \\
(0.000)\end{array}$ & & $\begin{array}{l}-0.017^{* * * *} \\
(0.000)\end{array}$ & & $\begin{array}{l}-0.018^{* * *} \\
(0.000)\end{array}$ \\
\hline $\operatorname{Ln}(O D A \text { loans } / G D P)_{, t-1}$ & & & $\begin{array}{l}-0.107^{*} \\
(0.053)\end{array}$ & $\begin{array}{l}-0.158^{* *} \\
(0.025)\end{array}$ & & & $\begin{array}{l}-0.150^{* *} \\
(0.014)\end{array}$ & $\begin{array}{l}-0.142^{*} \\
(0.064)\end{array}$ \\
\hline$[\mathrm{Ln}(\mathrm{OD} A \text { loans } / G D P)]_{, 2-1}^{2}$ & & & $\begin{array}{r}0.019^{*} \\
(0.062)\end{array}$ & $\begin{array}{r}0.027^{*} \\
(0.057)\end{array}$ & & & $\begin{array}{l}0.029^{* * *} \\
(0.008)\end{array}$ & $\begin{array}{c}0.022 \\
(0.143)\end{array}$ \\
\hline Ln (Offshore bank loans/GDP),t-1 & $\begin{array}{l}-0.907^{* * *} \\
(0.005)\end{array}$ & $\begin{array}{l}-0.938^{* * *} \\
(0.004)\end{array}$ & $\begin{array}{l}-0.916^{* * *} \\
(0.005)\end{array}$ & $\begin{array}{l}-0.905^{* * *} \\
(0.005)\end{array}$ & $\begin{array}{l}-0.842^{* * *} \\
(0.006)\end{array}$ & $\begin{array}{l}-0.866^{* * *} \\
(0.005)\end{array}$ & $\begin{array}{l}-0.819^{* * * *} \\
(0.009)\end{array}$ & $\begin{array}{l}-0.833^{* * *} \\
(0.007)\end{array}$ \\
\hline$[\mathrm{Ln} \text { (Offshore bank loans/GDP) }]_{,, t-1}^{2}$ & $\begin{array}{l}0.128^{* * *} \\
(0.000)\end{array}$ & $\begin{array}{l}0.134^{* * *} \\
(0.000)\end{array}$ & $\begin{array}{l}0.130^{* * *} \\
(0.000)\end{array}$ & $\begin{array}{l}0.129^{* * *} \\
(0.000)\end{array}$ & $\begin{array}{l}0.089^{* * *} \\
(0.005)\end{array}$ & $\begin{array}{l}0.093^{* * *} \\
(0.003)\end{array}$ & $\begin{array}{l}0.084^{* * *} \\
(0.007)\end{array}$ & $\begin{array}{l}0.088^{* * *} \\
(0.000)\end{array}$ \\
\hline Investment/GDP & $\begin{array}{l}0.001^{* * *} \\
(0.000)\end{array}$ & $\begin{array}{l}0.001^{* * *} \\
(0.000)\end{array}$ & $\begin{array}{l}0.002^{* * *} \\
(0.000)\end{array}$ & $\begin{array}{l}0.001^{* * *} \\
(0.000)\end{array}$ & $\begin{array}{l}0.002^{* * *} \\
(0.000)\end{array}$ & $\begin{array}{l}0.002^{* * *} \\
(0.000)\end{array}$ & $\begin{array}{l}0.002^{* * *} \\
(0.000)\end{array}$ & $\begin{array}{l}0.002^{* * *} \\
(0.000)\end{array}$ \\
\hline Government consumption/GDP & $\begin{array}{l}-0.004^{* * *} \\
(0.000)\end{array}$ & $\begin{array}{l}-0.004^{* * *} \\
(0.000)\end{array}$ & $\begin{array}{l}-0.003^{* * *} \\
(0.001)\end{array}$ & $\begin{array}{l}-0.004^{* * *} \\
(0.000)\end{array}$ & $\begin{array}{l}-0.009^{* * *} \\
(0.000)\end{array}$ & $\begin{array}{l}-0.009^{* * * *} \\
(0.000)\end{array}$ & $\begin{array}{l}-0.009^{* * *} \\
(0.000)\end{array}$ & $\begin{array}{l}-0.009^{* * *} \\
(0.000)\end{array}$ \\
\hline Ln (Initial GDP per capita) & $\begin{array}{l}-0.368 \\
(0.169)\end{array}$ & $\begin{array}{l}-0.258 \\
(0.340)\end{array}$ & $\begin{array}{l}-0.179 \\
(0.500)\end{array}$ & $\begin{array}{l}-0.232 \\
(0.388)\end{array}$ & $\begin{array}{c}0.725 \\
(0.435)\end{array}$ & $\begin{array}{c}0.763 \\
(0.407)\end{array}$ & $\begin{array}{c}0.837 \\
(0.354)\end{array}$ & $\begin{array}{c}0.862 \\
(0.345)\end{array}$ \\
\hline Ln (Inflation) & $\begin{array}{l}-0.018^{* * *} \\
(0.002)\end{array}$ & $\begin{array}{l}-0.017^{* * *} \\
(0.004)\end{array}$ & $\begin{array}{l}-0.012^{* * *} \\
(0.004)\end{array}$ & $\begin{array}{l}-0.019^{* * *} \\
(0.002)\end{array}$ & $\begin{array}{l}-0.037^{* * *} \\
(0.000)\end{array}$ & $\begin{array}{l}-0.038^{* * *} \\
(0.000)\end{array}$ & $\begin{array}{l}-0.036^{* * *} \\
(0.000)\end{array}$ & $\begin{array}{l}-0.038^{* * *} \\
(0.002)\end{array}$ \\
\hline Trade/GDP & $\begin{array}{l}0.001^{* *} \\
(0.049)\end{array}$ & $\begin{array}{l}0.001^{*} \\
(0.060)\end{array}$ & $\begin{array}{c}0.001 \\
(0.104)\end{array}$ & $\begin{array}{l}0.001^{*} \\
(0.062)\end{array}$ & $\begin{array}{c}0.001^{*} \\
(0.060)\end{array}$ & $\begin{array}{l}0.001^{*} \\
(0.055)\end{array}$ & $\begin{array}{c}0.001^{*} \\
(0.052)\end{array}$ & $\begin{array}{c}0.001^{*} \\
(0.060)\end{array}$ \\
\hline Voice \& accountability & $\begin{array}{l}0.041^{* * *} \\
(0.000)\end{array}$ & $\begin{array}{l}0.039^{* * * *} \\
(0.000)\end{array}$ & $\begin{array}{l}0.045^{* * *} \\
(0.000)\end{array}$ & $\begin{array}{l}0.039^{* * *} \\
(0.000)\end{array}$ & $\begin{array}{l}0.040^{* * *} \\
(0.007)\end{array}$ & $\begin{array}{l}0.043^{* * *} \\
(0.003)\end{array}$ & $\begin{array}{l}0.043^{* * *} \\
(0.003)\end{array}$ & $\begin{array}{l}0.042^{* * *} \\
(0.005)\end{array}$ \\
\hline $\begin{array}{l}\text { Time effects } \\
\text { Country fixed effects }\end{array}$ & $\begin{array}{l}\text { Yes } \\
\text { Yes }\end{array}$ & $\begin{array}{l}\text { Yes } \\
\text { Yes }\end{array}$ & $\begin{array}{l}\text { Yes } \\
\text { Yes }\end{array}$ & $\begin{array}{l}\text { Yes } \\
\text { Yes }\end{array}$ & Yes & Yes & Yes & Yes \\
\hline $\begin{array}{l}\text { \# of observations } \\
\text { \# of countries } \\
\text { Wald chi-square } \\
\text { Joint significance: aid \& aid sq. } \\
\text { Joint significance: loans \& loans sq. }\end{array}$ & $\begin{array}{l}1748 \\
130 \\
1759.7 \\
0.000\end{array}$ & $\begin{array}{l}1748 \\
130 \\
1668.9\end{array}$ & $\begin{array}{l}1748 \\
130 \\
1703.5\end{array}$ & $\begin{array}{l}1748 \\
130 \\
1703.4\end{array}$ & $\begin{array}{l}1617 \\
130 \\
412.8\end{array}$ & $\begin{array}{l}1617 \\
130 \\
430.62\end{array}$ & $\begin{array}{l}1617 \\
130 \\
415.3\end{array}$ & $\begin{array}{l}1617 \\
130 \\
427.7 \\
0.085 \\
\end{array}$ \\
\hline Marginal effect of ODA aid & 0.047 & & & & 0.041 & & & \\
\hline $\begin{array}{l}\text { Marginal effect of ODA grants } \\
\text { Marginal effect of ODA loans }\end{array}$ & & 0.050 & 0.078 & $\begin{array}{l}0.055 \\
0.104\end{array}$ & & 0.041 & 0.132 & $\begin{array}{l}0.043 \\
0.072\end{array}$ \\
\hline Marginal effect of bank loans & 0.616 & 0.657 & 0.631 & 0.630 & 0.217 & 0.241 & 0.181 & 0.214 \\
\hline Critical values grants/ODA loans $(\mathrm{X})$ & & 3.447 & & 3.048 & & 4.345 & & 2.963 \\
\hline Critical values grants/bank loans $(\mathrm{Y})$ & & & & 3.48 & & & & 4.377 \\
\hline
\end{tabular}




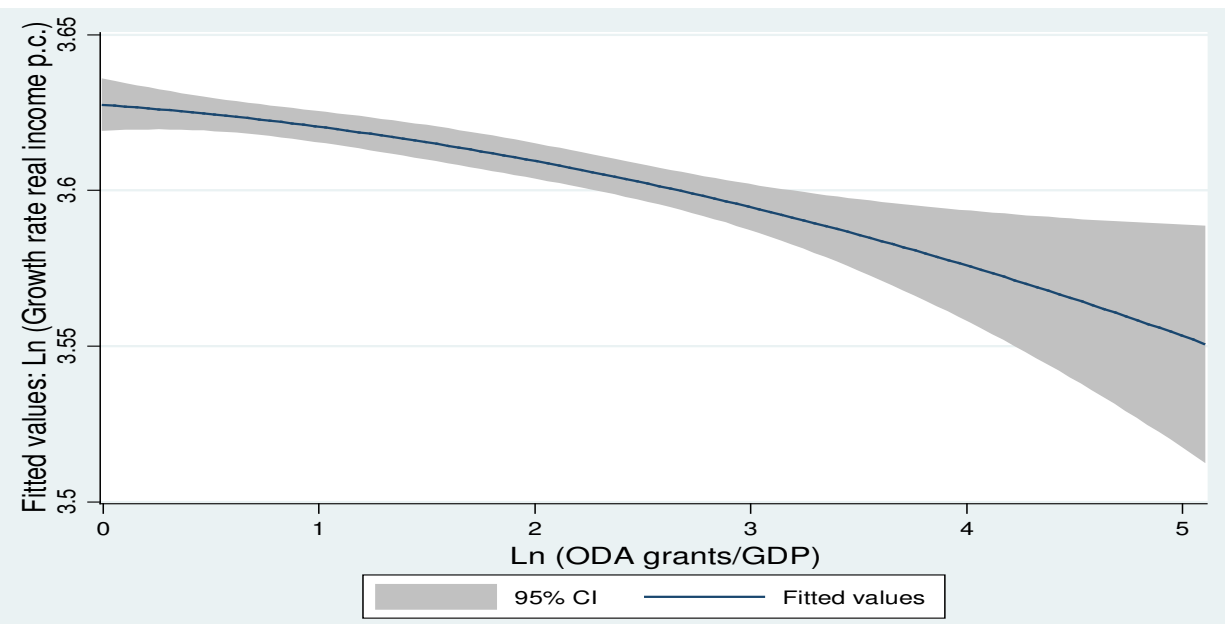

Figure 1. Income per capita and ODA grants

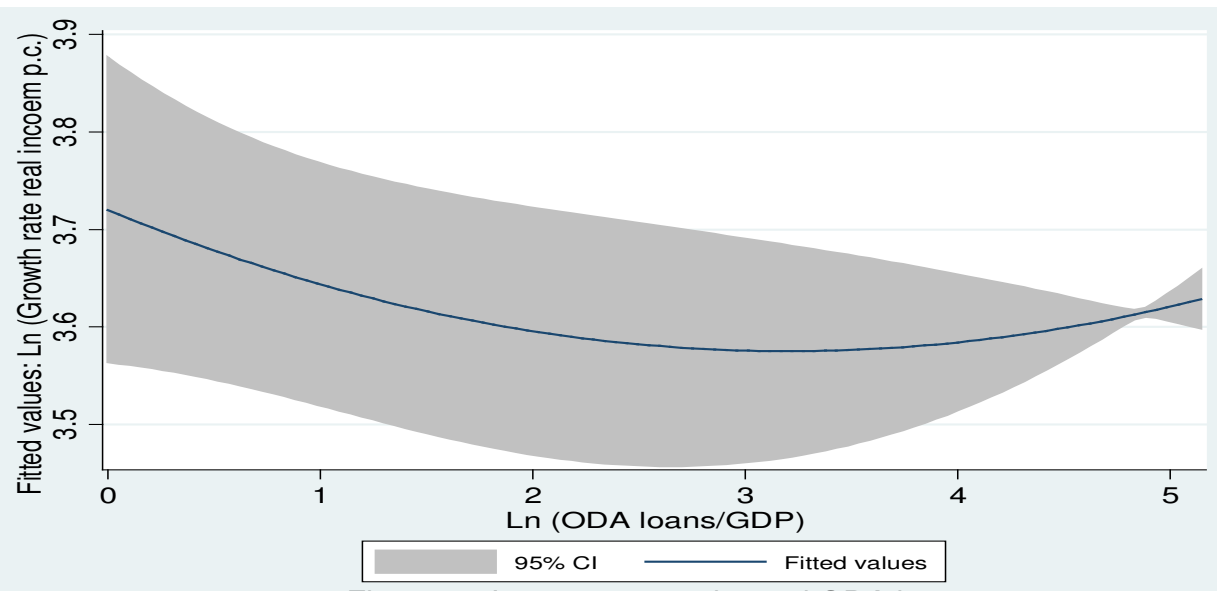

Figure 2. Income per capita and ODA loans

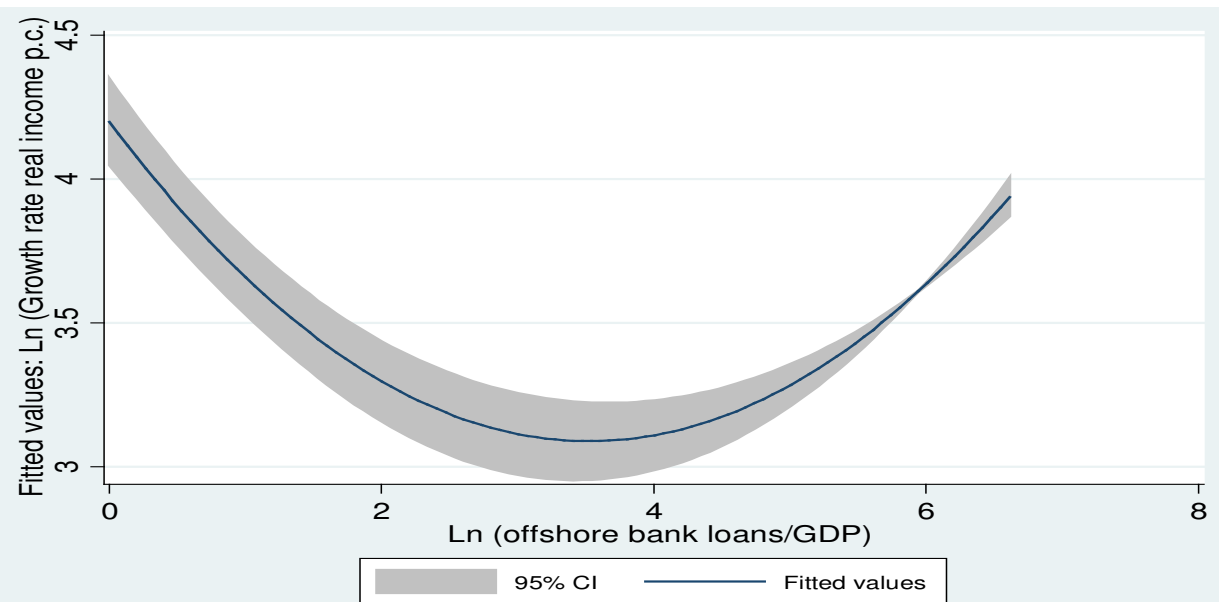

Figure 3. Income per capita and offshore bank loans 
Table 5

Dependent variable: Ln (Growth rate of real GDP per capita)

\begin{tabular}{|c|c|c|c|c|c|}
\hline Independent variables $\downarrow$ & $(1)$ & $(2)$ & $(3)$ & (4) & (5) \\
\hline Ln $(O D A \text { grants } / G D P)_{, t-1}$ & $\begin{array}{l}0.104^{* * *} \\
(0.000)\end{array}$ & $\begin{array}{l}0.102^{* * *} \\
(0.000)\end{array}$ & $\begin{array}{l}0.106^{* * *} \\
(0.000)\end{array}$ & $\begin{array}{l}0.110^{* * *} \\
(0.000)\end{array}$ & $\begin{array}{l}0.103^{* * *} \\
(0.000)\end{array}$ \\
\hline$[\mathrm{Ln}(\mathrm{OD} \text { A grants } / G D P)]^{2},{ }_{,-1}$ & $\begin{array}{l}-0.015^{* * *} \\
(0.001)\end{array}$ & $\begin{array}{l}-0.015^{* * *} \\
(0.001)\end{array}$ & $\begin{array}{l}-0.015^{* * *} \\
(0.001)\end{array}$ & $\begin{array}{l}-0.017^{* * *} \\
(0.000)\end{array}$ & $\begin{array}{l}-0.015^{* *-} \\
(0.001)\end{array}$ \\
\hline $\operatorname{Ln}(O D A \text { loans } / G D P)_{, t-1}$ & $\begin{array}{l}-0.182^{* * *} \\
(0.010)\end{array}$ & $\begin{array}{l}-0.178^{* *} \\
(0.012)\end{array}$ & $\begin{array}{l}-0.187^{* * *} \\
(0.025)\end{array}$ & $\begin{array}{l}-0.161^{\text {** }} \\
(0.021)\end{array}$ & $\begin{array}{l}-0.182^{\text {*** }} \\
(0.010)\end{array}$ \\
\hline$[\mathrm{Ln}(\mathrm{OD} A \text { loans } / G D P)]^{2}, t-1$ & $\begin{array}{l}0.032^{* *} \\
(0.022)\end{array}$ & $\begin{array}{l}0.032^{* *} \\
(0.024)\end{array}$ & $\begin{array}{l}0.034^{* *} \\
(0.018)\end{array}$ & $\begin{array}{l}0.028^{* *} \\
(0.046)\end{array}$ & $\begin{array}{l}0.033^{* *} \\
(0.021)\end{array}$ \\
\hline Ln (Offshore bank loans/GDP),t-1 & $\begin{array}{l}-1.065^{* * *} \\
(0.001)\end{array}$ & $\begin{array}{l}-1.013^{* * *} \\
(0.002)\end{array}$ & $\begin{array}{l}-1.049^{* * *} \\
(0.001)\end{array}$ & $\begin{array}{l}-1.017^{* * *} \\
(0.002)\end{array}$ & $\begin{array}{l}-1.037^{\text {*** }} \\
(0.001)\end{array}$ \\
\hline$[\mathrm{Ln}(\text { Offshore bank loans } / G D P)]^{2}, t-1$ & $\begin{array}{l}0.154^{* * *} \\
(0.000)\end{array}$ & $\begin{array}{l}0.146^{* * *} \\
(0.000)\end{array}$ & $\begin{array}{l}0.152^{* * *} \\
(0.000)\end{array}$ & $\begin{array}{l}0.146^{* * *} \\
(0.000)\end{array}$ & $\begin{array}{l}0.150^{* * *} \\
(0.000)\end{array}$ \\
\hline Investment/GDP & $\begin{array}{l}0.001^{* * * *} \\
(0.000)\end{array}$ & $\begin{array}{l}0.001^{* * *} \\
(0.000)\end{array}$ & $\begin{array}{l}0.001^{\text {**** }} \\
(0.000)\end{array}$ & $\begin{array}{l}0.001^{* * *} \\
(0.000)\end{array}$ & $\begin{array}{l}0.001^{\text {*** }} \\
(0.000)\end{array}$ \\
\hline Government consumption/GDP & $\begin{array}{l}-0.004^{* * *} \\
(0.000)\end{array}$ & $\begin{array}{l}-0.004^{* * *} \\
(0.000)\end{array}$ & $\begin{array}{l}-0.004^{* * *} \\
(0.000)\end{array}$ & $\begin{array}{l}-0.004^{\text {****}} \\
(0.000)\end{array}$ & $\begin{array}{l}-0.004^{* *} \\
(0.000)\end{array}$ \\
\hline Ln (Initial GDP per capita) & $\begin{array}{l}-0.150 \\
(0.572)\end{array}$ & $\begin{array}{l}-0.129 \\
(0.618)\end{array}$ & $\begin{array}{l}-0.092 \\
(0.721)\end{array}$ & $\begin{array}{l}-0.072 \\
(0.783)\end{array}$ & $\begin{array}{l}-0.071 \\
(0.785)\end{array}$ \\
\hline Ln (Inflation) & $\begin{array}{l}-0.032^{* * *} \\
(0.000)\end{array}$ & $\begin{array}{l}-0.024^{* * *} \\
(0.001)\end{array}$ & $\begin{array}{l}-0.027^{* * *} \\
(0.0020\end{array}$ & $\begin{array}{l}-0.025^{* * *} \\
(0.002)\end{array}$ & $\begin{array}{l}-0.026^{* * *} \\
(0.000)\end{array}$ \\
\hline Trade/GDP & $\begin{array}{l}0.001^{* * *} \\
(0.004)\end{array}$ & $\begin{array}{l}0.001^{* *} \\
(0.012)\end{array}$ & $\begin{array}{l}0.001^{* *} \\
(0.037)\end{array}$ & $\begin{array}{c}0.001^{* *} \\
(0.016)\end{array}$ & $\begin{array}{l}0.001^{* *} \\
(0.025)\end{array}$ \\
\hline Political stability & $\begin{array}{l}0.021^{\text {**** }} \\
(0.000)\end{array}$ & & & & \\
\hline Government effectiveness & & $\begin{array}{l}0.029^{* * *} \\
(0.006)\end{array}$ & & & \\
\hline Regulatory quality & & & $\begin{array}{l}0.013 \\
(0.154)\end{array}$ & & \\
\hline Rule of law & & & & $\begin{array}{l}0.002 \\
(0.823)\end{array}$ & \\
\hline Corruption & & & & & $\begin{array}{l}0.003 \\
(0.731)\end{array}$ \\
\hline Time effects & Yes & Yes & Yes & Yes & Yes \\
\hline Country fixed effects & Yes & Yes & Yes & Yes & Yes \\
\hline \# of observations & 1730 & 1737 & 1737 & 1748 & 1737 \\
\hline \# of countries & 130 & 130 & 130 & 130 & 130 \\
\hline Wald chi-square & 2059.5 & 2574.0 & 2334.3 & 2174.8 & 2231.9 \\
\hline Marginal effect of ODA grants & 0.061 & 0.059 & 0.063 & 0.061 & 0.060 \\
\hline Marginal effect of ODA loans & 0.129 & 0.133 & 0.143 & 0.111 & 0.139 \\
\hline Marginal effect of bank loans & 0.767 & 0.724 & 0.760 & 0.720 & 0.748 \\
\hline Critical values grants/ODA loans $(\mathrm{X})$ & 3.042 & 2.979 & 2.990 & 3.011 & 2.969 \\
\hline Critical values grants/bank loans (Y) & 3.459 & 3.463 & 3.458 & 3.458 & 3.455 \\
\hline
\end{tabular}

Notes: Same as for Table 4. 
Table 6

Dependent variable: Ln (Growth rate of real GDP per capita)

\begin{tabular}{|c|c|c|c|c|c|c|c|c|}
\hline \multirow{2}{*}{$\begin{array}{l}\text { Estimation technique } \rightarrow \\
\text { Independent variables } \downarrow\end{array}$} & \multicolumn{3}{|c|}{ FGLS-Fixed effects } & \multicolumn{4}{|c|}{ Difference-GMM } & \multirow[b]{2}{*}{$\begin{array}{l}\text { Income } \\
<75^{\text {th }} \mathrm{p} \text {. } \\
\text { (8) }\end{array}$} \\
\hline & $\begin{array}{l}\text { Income } \\
<25^{\text {th }} \mathrm{p} \text {. } \\
\text { (1) }\end{array}$ & $\begin{array}{l}\text { Income } \\
<50^{\text {th }} \mathrm{p} \text {. } \\
(2)\end{array}$ & $\begin{array}{l}\text { Income } \\
<\text { mean } \\
(3)\end{array}$ & $\begin{array}{l}\text { Income } \\
<75^{\text {th }} \mathrm{p} \text {. } \\
\text { (4) }\end{array}$ & $\begin{array}{l}\text { Income } \\
<25^{\text {th }} \mathrm{p} \text {. } \\
(5)\end{array}$ & $\begin{array}{l}\text { Income } \\
<50^{\text {th }} \mathrm{p} \text {. } \\
\quad(6)\end{array}$ & $\begin{array}{l}\text { Income } \\
<\text { mean } \\
(7)\end{array}$ & \\
\hline Ln $(O D A \text { grants } / G D P)_{, t-1}$ & $\begin{array}{l}0.240^{* * *} \\
(0.000)\end{array}$ & $\begin{array}{l}0.069^{* * *} \\
(0.005)\end{array}$ & $\begin{array}{l}0.070^{* * *} \\
(0.001)\end{array}$ & $\begin{array}{l}0.085^{* * *} \\
(0.000)\end{array}$ & $\begin{array}{c}0.010 \\
(0.905)\end{array}$ & $\begin{array}{c}0.063 \\
(0.177)\end{array}$ & $\begin{array}{c}0.106^{* *} \\
(0.014)\end{array}$ & $\begin{array}{l}0.135^{* * *} \\
(0.009)\end{array}$ \\
\hline$[\mathrm{Ln}(\mathrm{OD} \text { A grants } / G D P)]^{2}, t-1$ & $\begin{array}{l}-0.036^{* * *} \\
(0.005)\end{array}$ & $\begin{array}{l}-0.009 \\
(0.122)\end{array}$ & $\begin{array}{l}-0.008 \\
(0.104)\end{array}$ & $\begin{array}{l}-0.011^{* *} \\
(0.022)\end{array}$ & $\begin{array}{c}0.011 \\
(0.423)\end{array}$ & $\begin{array}{l}-0.001 \\
(0.874)\end{array}$ & $\begin{array}{l}-0.013 \\
(0.109)\end{array}$ & $\begin{array}{l}-0.019^{*} \\
(0.070)\end{array}$ \\
\hline $\operatorname{Ln}(O D A \text { loans } / G D P)_{, t-1}$ & $\begin{array}{l}-4.951^{* *} \\
(0.019)\end{array}$ & $\begin{array}{l}-4.292^{* *} \\
(0.012)\end{array}$ & $\begin{array}{l}-0.175^{* *} \\
(0.016)\end{array}$ & $\begin{array}{l}-0.166^{* *} \\
(0.020)\end{array}$ & $\begin{array}{l}-8.700^{* *} \\
(0.000)\end{array}$ & $\begin{array}{l}-8.017^{* *} \\
(0.000)\end{array}$ & $\begin{array}{l}-0.303^{* *} \\
(0.025)\end{array}$ & $\begin{array}{c}-0.278^{*} \\
(0.060)\end{array}$ \\
\hline$[\mathrm{Ln}(\mathrm{OD} A \text { loans } / G D P)]^{2}{ }_{, t-1}$ & $\begin{array}{l}0.526^{* *} \\
(0.021)\end{array}$ & $\begin{array}{l}0.467^{* * *} \\
(0.011)\end{array}$ & $\begin{array}{l}0.034^{* *} \\
(0.024)\end{array}$ & $\begin{array}{c}0.031^{* *} \\
(0.036)\end{array}$ & $\begin{array}{l}0.992^{* * *} \\
(0.000)\end{array}$ & $\begin{array}{l}0.897^{* * *} \\
(0.000)\end{array}$ & $\begin{array}{c}0.057^{* *} \\
(0.053)\end{array}$ & $\begin{array}{c}0.050 \\
(0.123)\end{array}$ \\
\hline Ln (Offshore bank loans / GDP),t-1 & $\begin{array}{l}-1.536^{* * *} \\
(0.009)\end{array}$ & $\begin{array}{l}-1.477^{* * *} \\
(0.006)\end{array}$ & $\begin{array}{l}-1.141^{* * *} \\
(0.003)\end{array}$ & $\begin{array}{l}-1.076^{* * *} \\
(0.005)\end{array}$ & $\begin{array}{l}-1.539^{* * *} \\
(0.000)\end{array}$ & $\begin{array}{l}-1.625^{* * *} \\
(0.000)\end{array}$ & $\begin{array}{l}-1.639^{* * *} \\
(0.000)\end{array}$ & $\begin{array}{l}-1.650^{* * *} \\
(0.000)\end{array}$ \\
\hline$[\mathrm{Ln} \text { (Offshore bank loans/GDP) }]^{2}, t-1$ & $\begin{array}{l}0.237^{* * * *} \\
(0.006)\end{array}$ & $\begin{array}{l}0.227^{* * * *} \\
(0.000)\end{array}$ & $\begin{array}{l}0.171^{* * *} \\
(0.000)\end{array}$ & $\begin{array}{l}0.159^{* * * *} \\
(0.001)\end{array}$ & $\begin{array}{l}0.203^{* * *} \\
(0.000)\end{array}$ & $\begin{array}{l}0.217^{* * *} \\
(0.000)\end{array}$ & $\begin{array}{l}0.219^{* * * *} \\
(0.000)\end{array}$ & $\begin{array}{l}0.221^{* * *} \\
(0.000)\end{array}$ \\
\hline Investment/GDP & $\begin{array}{c}0.002^{* *} \\
(0.018)\end{array}$ & $\begin{array}{c}0.001^{*} \\
(0.060)\end{array}$ & $\begin{array}{c}0.001^{* *} \\
(0.049)\end{array}$ & $\begin{array}{c}0.001^{*} \\
(0.056)\end{array}$ & $\begin{array}{l}0.008^{* * *} \\
(0.000)\end{array}$ & $\begin{array}{l}0.006^{* * *} \\
(0.001)\end{array}$ & $\begin{array}{c}0.003^{*} \\
(0.056)\end{array}$ & $\begin{array}{c}0.003 \\
(0.162)\end{array}$ \\
\hline Government consumption/GDP & $\begin{array}{l}-0.005^{* * *} \\
(0.011)\end{array}$ & $\begin{array}{l}-0.005^{* * *} \\
(0.000)\end{array}$ & $\begin{array}{l}-0.005^{* * *} \\
(0.000)\end{array}$ & $\begin{array}{l}-0.005^{* * *} \\
(0.000)\end{array}$ & $\begin{array}{l}-0.013^{* * *} \\
(0.000)\end{array}$ & $\begin{array}{l}-0.015^{* * *} \\
(0.000)\end{array}$ & $\begin{array}{l}-0.011^{* * *} \\
(0.000)\end{array}$ & $\begin{array}{l}-0.012^{* * *} \\
(0.000)\end{array}$ \\
\hline Ln (Initial GDP per capita) & $\begin{array}{l}-1.023 \\
(0.267)\end{array}$ & $\begin{array}{l}-1.699^{* * *} \\
(0.267)\end{array}$ & $\begin{array}{l}-1.117^{* * *} \\
(0.001)\end{array}$ & $\begin{array}{l}-0.934^{* * *} \\
(0.004)\end{array}$ & $\begin{array}{l}-3.271^{* * *} \\
(0.002)\end{array}$ & $\begin{array}{l}-3.795^{* * *} \\
(0.000)\end{array}$ & $\begin{array}{l}-2.050^{* * *} \\
(0.001)\end{array}$ & $\begin{array}{l}-1.451^{* *} \\
(0.023)\end{array}$ \\
\hline Ln (Inflation) & $\begin{array}{l}-0.050^{* * *} \\
(0.005)\end{array}$ & $\begin{array}{l}-0.041^{* * *} \\
(0.001)\end{array}$ & $\begin{array}{l}-0.037^{* * *} \\
(0.001)\end{array}$ & $\begin{array}{l}-0.045^{* * *} \\
(0.000)\end{array}$ & $\begin{array}{l}-0.020 \\
(0.116)\end{array}$ & $\begin{array}{l}-0.059^{* * *} \\
(0.000)\end{array}$ & $\begin{array}{l}-0.056^{* * *} \\
(0.000)\end{array}$ & $\begin{array}{l}-0.058^{* * *} \\
(0.000)\end{array}$ \\
\hline Trade/GDP & $\begin{array}{c}0.0003 \\
(0.920)\end{array}$ & $\begin{array}{l}-0.0001 \\
(0.610)\end{array}$ & $\begin{array}{c}0.0001 \\
(0.401)\end{array}$ & $\begin{array}{c}0.0002 \\
(0.103)\end{array}$ & $\begin{array}{c}0.001 \\
(0.116)\end{array}$ & $\begin{array}{c}0.0004 \\
(0.306)\end{array}$ & $\begin{array}{c}0.0001 \\
(0.844)\end{array}$ & $\begin{array}{c}-0.0001 \\
(0.788)\end{array}$ \\
\hline Voice \& accountability & $\begin{array}{l}0.061^{* * *} \\
(0.003)\end{array}$ & $\begin{array}{l}0.058^{* * *} \\
(0.000)\end{array}$ & $\begin{array}{l}0.042^{* * *} \\
(0.000)\end{array}$ & $\begin{array}{l}0.041^{* * *} \\
(0.000)\end{array}$ & $\begin{array}{l}0.206^{* * *} \\
(0.000)\end{array}$ & $\begin{array}{l}0.124^{* * *} \\
(0.002)\end{array}$ & $\begin{array}{l}0.091^{* * *} \\
(0.009)\end{array}$ & $\begin{array}{c}0.064^{*} \\
(0.065)\end{array}$ \\
\hline Lagged dependent variable & & & & & $\begin{array}{c}0.005 \\
(0.747)\end{array}$ & $\begin{array}{l}0.070^{* * *} \\
(0.000)\end{array}$ & $\begin{array}{l}0.084^{* * *} \\
(0.000)\end{array}$ & $\begin{array}{l}0.111^{* * *} \\
(0.000)\end{array}$ \\
\hline Time effects & Yes & Yes & Yes & Yes & Yes & Yes & Yes & Yes \\
\hline Country fixed effects & Yes & Yes & Yes & Yes & & & & \\
\hline \# of observations & 433 & 871 & 1207 & 1317 & 398 & 801 & 1112 & 1216 \\
\hline \# of countries & 38 & 71 & 94 & 101 & 38 & 72 & 94 & 101 \\
\hline \# of instruments & & & & & 39 & 39 & 39 & 39 \\
\hline Wald chi-square & 417.0 & 2880.2 & 1517.6 & 1522.6 & & & & \\
\hline Sargan test $\mathrm{t}^{1}$ & & & & & 0.363 & 0.188 & 0.245 & 0.224 \\
\hline $\begin{array}{l}\text { Autocorrelation test } \mathrm{t}^{2} \\
\text { Joint significance: aid \& aid sq. } \\
\text { Joint significance: loans \& loans sq. }\end{array}$ & & 0.000 & 0.000 & & 0.265 & 0.268 & $\begin{array}{l}0.232 \\
0.002\end{array}$ & $\begin{array}{l}0.275 \\
0.000\end{array}$ \\
\hline Marginal effect of ODA grants & 0.067 & 0.033 & 0.041 & 0.047 & & & 0.059 & 0.069 \\
\hline Marginal effect of ODA loans & 0.165 & 0.250 & 0.155 & 0.135 & 0.946 & 0.707 & 0.251 & 0.208 \\
\hline Marginal effect of bank loans & 1.281 & 1.222 & 0.893 & 0.815 & 0.875 & 0.955 & 0.965 & 0.979 \\
\hline Critical values grants/ODA loans $(\mathrm{X})$ & 4.618 & 4.581 & 2.917 & 2.988 & & & 2.921 & 2.993 \\
\hline Critical values grants/bank loans $(\mathrm{Y})$ & 3.253 & 3.276 & 3.383 & 3.415 & & & 3.761 & 3.719 \\
\hline
\end{tabular}


Appendix A: List of 131 developing countries in our study.

\begin{tabular}{|c|c|c|c|}
\hline Albania & Djibouti & Libya & Serbia \\
\hline Algeria & Dominica & Macedonia & Seychelles \\
\hline Angola & Dominican Republic & Madagascar & Sierra Leone \\
\hline Argentina & Ecuador & Malawi & Slovenia \\
\hline Armenia & El Salvador & Malaysia & Solomon Islands \\
\hline Azerbaijan & Equatorial Guinea & Maldives & South Africa \\
\hline Bahrain & Eritrea & Mali & Sri Lanka \\
\hline Bangladesh & Ethiopia & Malta & St. Lucia \\
\hline Barbados & Fiji & Mauritania & St. Vincent \& Grenadines \\
\hline Belarus & Gabon & Mauritius & Sudan \\
\hline Belize & Gambia & Mexico & Suriname \\
\hline Benin & Georgia & Moldova & Swaziland \\
\hline Bhutan & Ghana & Mongolia & Syrian Arab Republic \\
\hline Bolivia & Grenada & Morocco & Tajikistan \\
\hline Botswana & Guatemala & Mozambique & Tanzania \\
\hline Brazil & Guinea & Namibia & Thailand \\
\hline Burkina Faso & Guinea-Bissau & Nepal & Togo \\
\hline Burundi & Guyana & Nicaragua & Tonga \\
\hline Cambodia & Haiti & Niger & Trinidad and Tobago \\
\hline Cameroon & Honduras & Nigeria & Tunisia \\
\hline Cape Verde & India & Oman & Turkey \\
\hline Central African Republic & Indonesia & Pakistan & Turkmenistan \\
\hline Chad & Iran, Islamic Republic & Palau & Uganda \\
\hline Chile & Jamaica & Panama & Ukraine \\
\hline China & Jordan & Papua New Guinea & Uruguay \\
\hline Colombia & Kazakhstan & Paraguay & Uzbekistan \\
\hline Comoros & Kenya & Peru & Vanuatu \\
\hline Congo, Democratic Republic & Kiribati & Philippines & Venezuela \\
\hline Congo, Republic & Kyrgyz Republic & Rwanda & Vietnam \\
\hline Costa Rica & Laos & Samoa & Yemen, Republic \\
\hline Cote d'Ivoire & Lebanon & Sao Tome \& Principe & Zambia \\
\hline Croatia & Lesotho & Saudi Arabia & Zimbabwe \\
\hline Cuba & Liberia & Senegal & \\
\hline
\end{tabular}

